\title{
Diversifikasi Olahan Ikan Pada Wanita Kaum Ibu GPIJS Kota Bitung Provinsi Sulawesi Utara
}

\author{
Verly Dotulong dan Lita A. D. Y. Montolalu
}

\author{
Program Studi Teknologi Hasil Perikanan \\ Fakultas Perikanan dan Ilmu Kelautan, Universitas Sam Ratulangi. \\ J1. Kampus Unsrat Bahu, Manado 95115, Sulawesi Utara, Indonesia. \\ *Penulis Korespondensi: verlydotulong@yahoo.co.id \\ (Diterima 13-10-2020; Direvisi 07-01-2021; Dipublikasi 30-01-2021)
}

\begin{abstract}
Fish contains high protein, cheaper, easy to obtain and lawful for all groups of society in terms of health and religion. Therefore, the Movement to Promote Fish Eating (GEMARIKAN) must be implemented. One way is to diversify processed fishery products. The Fishery Product Technology Study Program carried out a Community Partnership Program for the Women Groups (WKI) of the Holy Street Evangelical Church (GPIJS) Bitung City. This group is domiciled in Manembo-Nembo Village, Matuari District, including in the Bitung City area, \pm 51 $\mathrm{km}$ from the Unsrat campus with 59 people, most of whom are teenagers and children. The part-time job of the head of the family is mostly fishermen whose catch of fish is often abundant and cannot be fully utilized. Diversification of processed fish products is one way to maintain fish quality and increase fish consumption, especially for adolescents and children to improve nutrition. This partnership program carries out training and mentoring on the processing of flying fish nuggets and dragon legs (Decapterus sp.) With fish portions of 60\% and $80 \%$. The results showed that the highest consumer acceptance of fish nuggets and dragon feet in terms of color, texture, taste and level of preference was found in fish nuggets and fish dragon feet products with a fish concentration of $80 \%$.
\end{abstract}

\begin{abstract}
Keywords: WKI GPIJS, fish nugget, fish drumstick
Ikan mengandung protein yang tinggi, murah harganya, mudah diperoleh dan halal untuk semua golongan ditinjau dari segi kesehatan maupun agama, oleh karena itu Gerakan Memasyarakatkan Makan Ikan (GEMARIKAN) harus dilaksanakan, salah satu cara adalah dengan melakukan diversifikasi produk olahan hasil perikanan. Berdasarkan hal ini maka FPIK Unsrat, khususnya Program Studi Teknologi Hasil Perikanan melakukan Program Kemitraan Masyarakat pada Kelompok Wanita Kaum Ibu (WKI) Gereja Pekabaran Injil Jalan Suci (GPIJS) Kota Bitung. Kelompok ini berdomisili di Kelurahan Manembo-Nembo Kecamatan Matuari, termasuk di wilayah Kota Bitung berjarak $\pm 51 \mathrm{~km}$ dari kampus Unsrat dengan Jumlah jiwa 59, sebagian besar adalah remaja dan anak-anak. Pekerjaan sambilan kepala keluarga sebagian besar adalah nelayan dengan hasil tangkapan ikan yang sering melimpah dan tidak bisa dimanfaatkan maksimal. Diversifikasi produk olahan ikan merupakan salah satu cara untuk mempertahankan mutu ikan dan meningkatkan konsumsi makan ikan terutama bagi remaja dan anakanak untuk peningkatan gizi. Program kemitraan ini melaksanakan pelatihan dan pendampingan tentang pengolahan nugget dan kaki naga ikan layang (Decapterus sp.) dengan porsi ikan 60\% dan $80 \%$. Hasil kegiatan menunjukkan bahwa penerimaan konsumen terbanyak terhadap nugget dan kaki naga ikan dari segi warna, tekstur, citarasa dan tingkat kesukaan ditemukan pada produk nugget dan kaki naga ikan dengan konsentrasi ikan $80 \%$.
\end{abstract}

Kata kunci: WKI GPIJS, nugget ikan, kaki naga ikan.

\section{PENDAHULUAN}

Protein ikan sebagai sumber gizi penting baik bagi orang dewasa maupun anak-anak karena mengandung asam amino esensial yang harus dimasukkan dari luar tubuh melalui asupan makanan, dimana kadar protein ikan tergolong tinggi yaitu 18-20\% (Suweta, 1997). Selain protein, ikan juga mengandung banyak asam lemak tak jenuh omega-3 seperti EPA dan DHA (Maarse, 1991) yang bermanfaat meningkatkan kecerdasan otak anak-anak dan mencegah penyakit jantung arteroklerosis bagi orang dewasa. Gerakan Memasyarakatkan Makan Ikan (GEMARIKAN) adalah salah satu upaya Kementerian Kelautan dan Perikanan untuk meningkakan konsumsi makan ikan bagi masyarakat Indonesia (Anonimous, 2007). Berdasarkan Surat Keputusan Menteri Kelautan dan Perikanan RI Nomor 29/MEN/2006 tanggal 26 September 2006 dibentuk FORIKAN (Forum Peningkatan Konsumsi Ikan). FORIKAN bertujuan untuk mensosialisasikan dan mensinergikan program/kegiatan Program Nasional GEMARIKAN. Posisi FORIKAN ini sangat penting dalam upaya menunjang program pemerintah untuk peningkatan mutu dan diversifikasi produk olahan hasil perikanan, mengingat pentingnya mengkonsumsi ikan untuk kesehatan maupun meningkatkan kecerdasan. 
Harga ikan olahan tradisional murah karena porsi ikan yang kecil dalam produk tersebut, rendahnya mutu dan nutrisi, serta pengolahannya kurang memenuhi standar sanitasi dan higienis (Endang, 2013). Olahan berbahan ikan dewasa ini mulai dikembangkan yaitu meliputi bakso ikan, nugget ikan, kue ikan, kaki naga ikan, dan sebagainya (Purnomo, 2002; Kumolontang dan Indriati, 2011; Masita dan Sukesi, 2015). Untuk mempertahankan mutu ikan, salah satu cara yang ditempuh adalah mengolah ikan tersebut melalui diversifikasi olahan ikan dengan menggunakan ikan yang bermutu sangat segar, cara pengolahan yang memenuhi syarat sanitasi dan porsi ikan yang tinggi. Dotulong dan Montolalu (2019), melaporkan bahwa nugget dan kaki naga ikan hasil PKM pada WKI GMIM Solafide Kelurahan Girian Indah Kota Bitung diterima sangat baik oleh masyarakat dengan nilai rasa, aroma dan tekstur lebih besar dari 8.

Berdasarkan hal-hal di atas maka Fakultas Perikanan dan Ilmu Kelautan Unsrat, melalui Tim PKM dari Program Studi Teknologi Hasil Perikanan melakukan Program Kemitraan Masyarakat pada Kelompok Wanita Kaum Ibu GPIJS yang sebagiannya adalah istri nelayan. Kelompok WKI ini termasuk di wilayah Kota Bitung berjarak $\pm 51 \mathrm{~km}$ dari kampus Unsrat. Dua jenis olahan ikan yang diterapkan pada kegiatan Program Kemitraan Masyarakat dengan Kelompok Wanita kaum Ibu Gereja Pekabaran Injil Jalan Suci (GPIJS) kota Bitung adalah membuat produk nugget dan kaki naga ikan berbahan baku ikan layang (Decapterus sp.) yang lezat, bernilai gizi tinggi karena mempunyai porsi ikan $60 \%$ dan $80 \%$ serta sangat digemari oleh anak-anak balita. Digunakannya ikan Layang dalam kegiatan ini dikarenakan jenis ikan ini melimpah di kota Bitung dan mempunyai harga yang lebih murah dibandingkan dengan harga ikan segar lainnya.

Kelompok WKI Jemaat GPIJS Kota Bitung ini berdomisili di Kelurahan Manembo-Nembo Kecamatan Matuari. Mitra(WKI GPIJS) terdiri dari 15 KK dengan jumlah jiwa 59, dengan tingkat pendidikan SD 20 jiwa, SMP 10 jiwa, SLTA 14, Sarjana 4 jiwa, sisanya adalah anak-anak balita, fasilitas pendidikan yang ada yaitu: 1 TK, 1 SD, 1 SMP dan 1 SMA. Penduduk yang berprofesi sebagai nelayan ini tergolong masyarakat miskin, sehingga yang menjadi mitra sasaran program ini adalah Wanita Kaum Ibu (WKI).

Berdasarkan wawancara dengan WKI dalam Focus Group Discussion (FGD) Para wanita termasuk didalamnya para istri.

Nelayan tergabung dalam organisasi WKI GPIJS Kelurahan Manembo-Nembo. Pendidikan mereka rata-rata SD dan SMP usia 20-45 tahun. Kegiatan mereka sehari-hari sebagai ibu rumah tangga dan juga aktif dalam kegiatan keagamaan (ibadah). Sekali dalam seminggu, mereka melakukan pertemuan yang berhubungan dengan kegiatan WKI (ibadah), kadang-kadang dilanjutkan dengan rapat membicarakan kegiatan dalam kelompok tersebut. Para anggota WKI yang adalah istri nelayan ini keluarganya masih hidup di bawah garis kemiskinan, dengan pendapatan rata-rata perkapita per bulan Rp 500.000.

Tujuan dari kegiatan PKM ini adalah melatih ibu-ibu WKI yang menjadi mitra mengenai teknologi diversifikasi (penganekargaman) olahan ikan seperti nugget ikan dan kaki naga ikan dengan porsi ikan yang lebih banyak. Hal ini bermanfaat untuk peningkatan gizi dan juga menambah pendapatan serta memperluas wawasan ibu-ibu WKI dalam memandang olahan ikan sebagai prospek pengembangan usaha yang menjanjikan, sehingga menciptakan lapangan kerja baru.

\section{METODE PENELITIAN}

Program ini melibatkan mahasiswa tingkat akhir pada Program Studi Teknologi Hasil Perikanan FPIK-UNSRAT. Berhubung kegiatan ini dilaksanakan dalam masa pandemik Covid-19 maka diterapkan protokol kesehatan yaitu menggunakan masker, mencuci tangan dan menjaga jarak antar peserta.

Metode pendekatan yang ditawarkan untuk mendukung realisasi Program Kemitraan Masyarakat ini adalah berupa:

1. Penyuluhan (Gambar 1). Hal ini bertujuan mengubah perilaku anggota kelompok ke arah yang lebih baik menyangkut perlunya diverfsifikasi olahan ikan yang dapat dikembangkan menjadi usaha bisnis di bidang pangan hasil perikanan. 


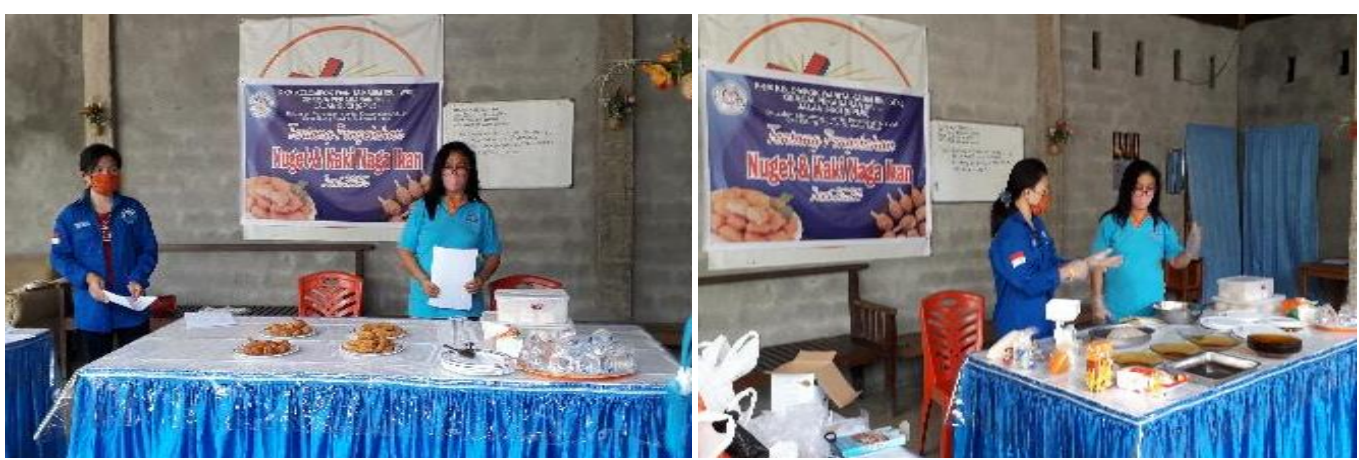

Gambar 1. Kegiatan Penyuluhan kepada wanita kaum ibu GPIJS kota Bitung.

\section{Kandungan Gizi ikan}

\section{a. Protein}

Penjelasan yang diberikan adalah tentang protein ikan yang kaya akan asam amino esensil yaitu asam amino yang harus dimasukkan ke dalam tubuh melalui asupan makanan karena tidak bisa disintesis di dalam tubuh, dimana asam-asam amino ini berperan dalam perkembangan otak anak-anak balita dan pertahanan tubuh bagi orang dewasa. Hal ini mengharuskan konsumen harus mengkonsumsi ikan untuk mendapatkan asam amino esensial tersebut.

\section{b. Asam Lemak}

Penjelasan yang diberikan tentang lemak ikan adalah bahwa lemak ikan kaya akan asam lemak omega tiga yaitu EPA dan DHA yang sangat bermanfaat baik untuk meningkatkan kecerdasan otak anak balita. Asam lemak omega tiga ini juga berfungsi mencegah dan mengobati beberapa penyakit berbahaya bagi orang dewasa seperti tekanan darah tinggi dan jantung arteroklerosis.

\section{Kesegaran Ikan}

Dalam kegiatan penyuluhan ini Tim PKM memberikan penjelasan kepada mitra bahwa kesegaran ikan merupakan hal prioritas yang harus diperhatikan, dimana bahan baku ikan yang akan diolah menjadi nugget dan kaki naga ikan adalah ikan yang mempunyai kesegaran tinggi karena berhubungan dengan gizi dari ikan tersebut. Penanganan ikan segar harus diperhatikan yaitu penerapan suhu rendah yaitu $0^{\circ} \mathrm{C}$ pada ikan agar komponen gizinya ikan tidak rusak dan dapat dimanfaatkan maksimal oleh konsumen.

\section{Diversifikasi Olahan Ikan}

Penjelasan tentang diversifikasi diawali dengan memperkenalkan produk olahan ikan yang mempunyai rasa yang gurih dan bentuk yang menarik adalah nugget ikan dan kaki naga ikan. Bentuk kedua produk ini seperti kue yang bisa dijadikan kudapan sehat untuk anak-anak balita agar supaya bisa meningkatkan selera makan ikan, hal ini dapat membentuk pola pikir ibu-ibu bahwa penting melakukan diversifikasi olahan ikan. Dijelaskan pula bahwa diversifikasi penting untuk memperpanjang masa simpan karena ikan dapat menghambat aktivitas mikro organisme pembusuk yang dapat merusak produk pangan.

Gizi dari nugget maupun kaki naga ikan tergantung dari jumlah ikan yang digunakan dalam adonan, dimana makin banyak jumlah ikan dibandingkan tepung maka gizi produk akan semakin baik. Dijelaskan pula bahwa kegiatan PKM ini bertujuan menggalakkan masyarakat untuk makan ikan dalam porsi yang banyak terutama untuk ibu-ibu hamil dan anak-anak balita mengingat pentingnya kandungan protein dan asam lemak omega-3 yang adalah komponen kimia pangan yang khas pada ikan (Diana, 2012) dimana lemak ikan banyak mengandung asam-asam lemak omega tiga dan enam seperti ETA, EPA dan DHA (Maarse, 1991). 


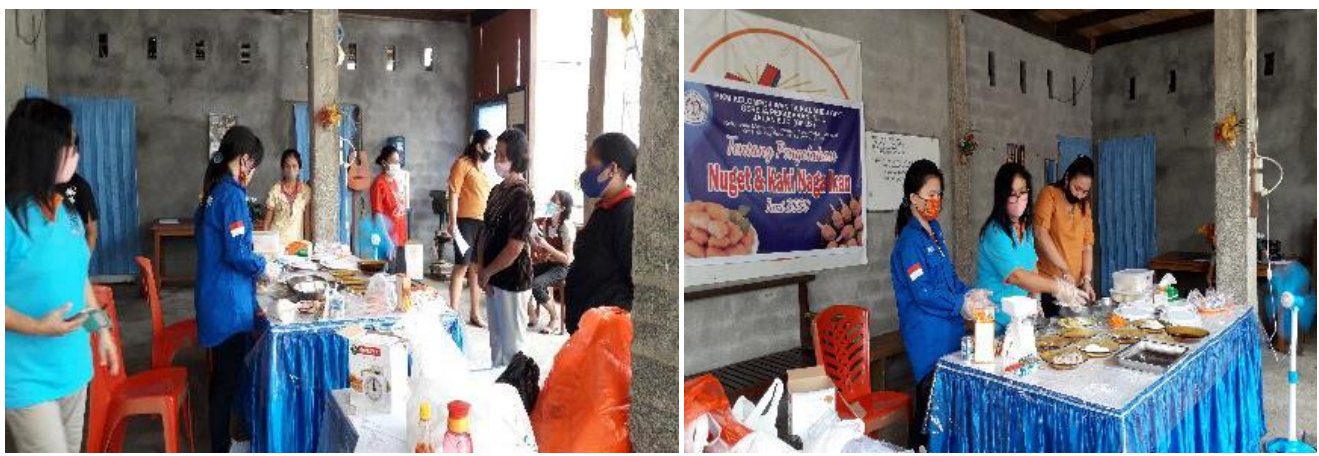

Gambar 2. Dokumentasi Kegiatan Pelatihan

2. Pelatihan (Gambar 2). Setelah kegiatan penyuluhan dilanjutkan dengan pelatihan bagi ibu-ibu sebagai sasaran program ini. Tujuan metode ini ialah untuk memberikan keterampilan dalam menghasilkan produk olahan ikan seperti nugget ikan dan kaki naga ikan. Pelatihan dilakukan dengan memanfaatkan staf dosen dan mahasiswa S1 Fakultas Perikanan dan Ilmu Kelautan Unsrat. Pemberdayaan dilakukan sebagai pemecahan masalah prioritas yaitu penerapan teknologi pengolahan hasil perikanan dan diversifikasi olahan hasil laut (nugget ikan dan kaki naga ikan).

Nugget ikan merupakan produk diversifikasi pengolahan hasil perikanan yang diadopsi dari luar Indonesia, berupa campuran daging ikan lumat dengan tepung tapioka, bumbu-bumbu seperti bawang putih, bawang bombay, garam dan tepung tapioka, selanjutnya dibuat berbentuk lempeng atau empat persegi panjang, dikukus, dipotong sesuai selera, dilapisi tepung roti atau panir. Perbandingan yang baik yang akan menghasilkan nugget dengan tekstur dan rasa yang enak. Kaki naga ikan adalah jenis olahan ikan dimana ikan ditambah tepung (tapioka, tepung bumbu) dibuat pasta dan ditambah bumbu-bumbu seperti lada, garam, bawang bombay, wortel dan telur, kemudian dibentuk bulat lonjong dan ditusuk dengan tongkat es cream, dikukus kemudian dilumuri tepung roti selanjutnya digoreng.

3. Pendampingan (Gambar 3), dilakukan kepada ibu-ibu untuk meningkatkan kemampuan mereka dalam hal mengolah nugget dan kaki naga ikan yang memenuhi standar sanitasi dan higienis serta bernilai gizi tinggi. Dalam kegiatan pendampingan ini dibuat nugget dan kaki naga ikan dengan menggunakan porsi ikan $60 \%$ dan $80 \%$ dengan tujuan untuk peningkatan gizi konsumen.

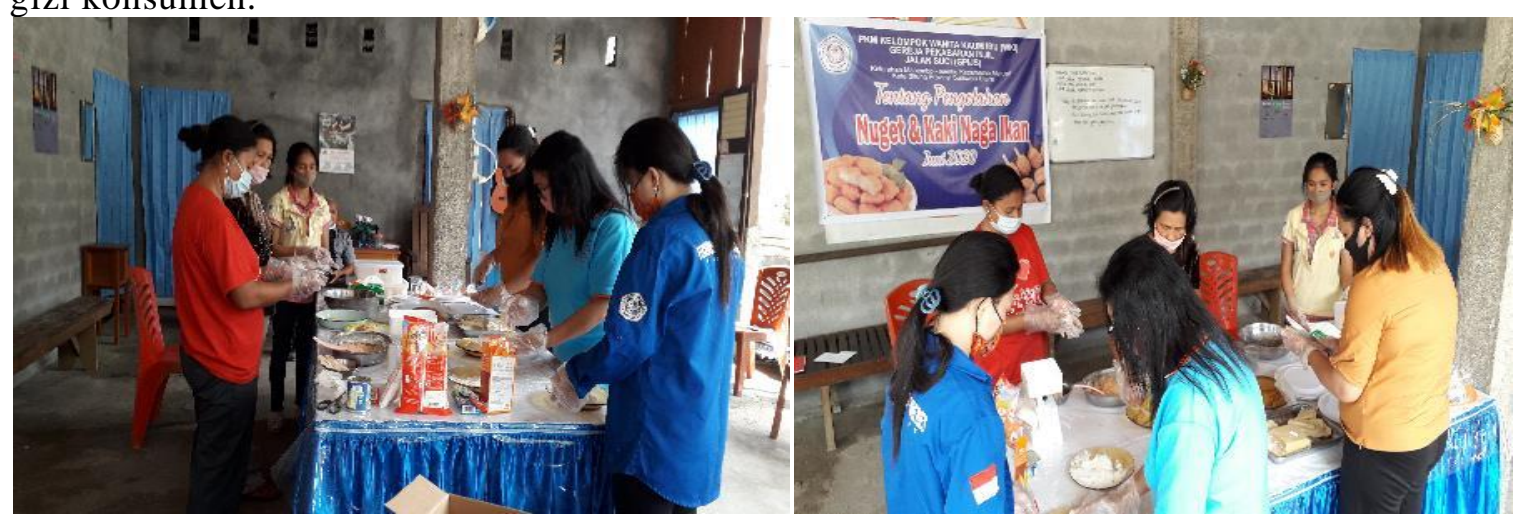

Gambar3. Dokumentasi kegiatan pendampingan.

Prosedur pembuatan nugget dan kaki naga ikan yang diterapkan dalam kegiatan pendampingan ini dapat dilihat pada Gambar 4. 


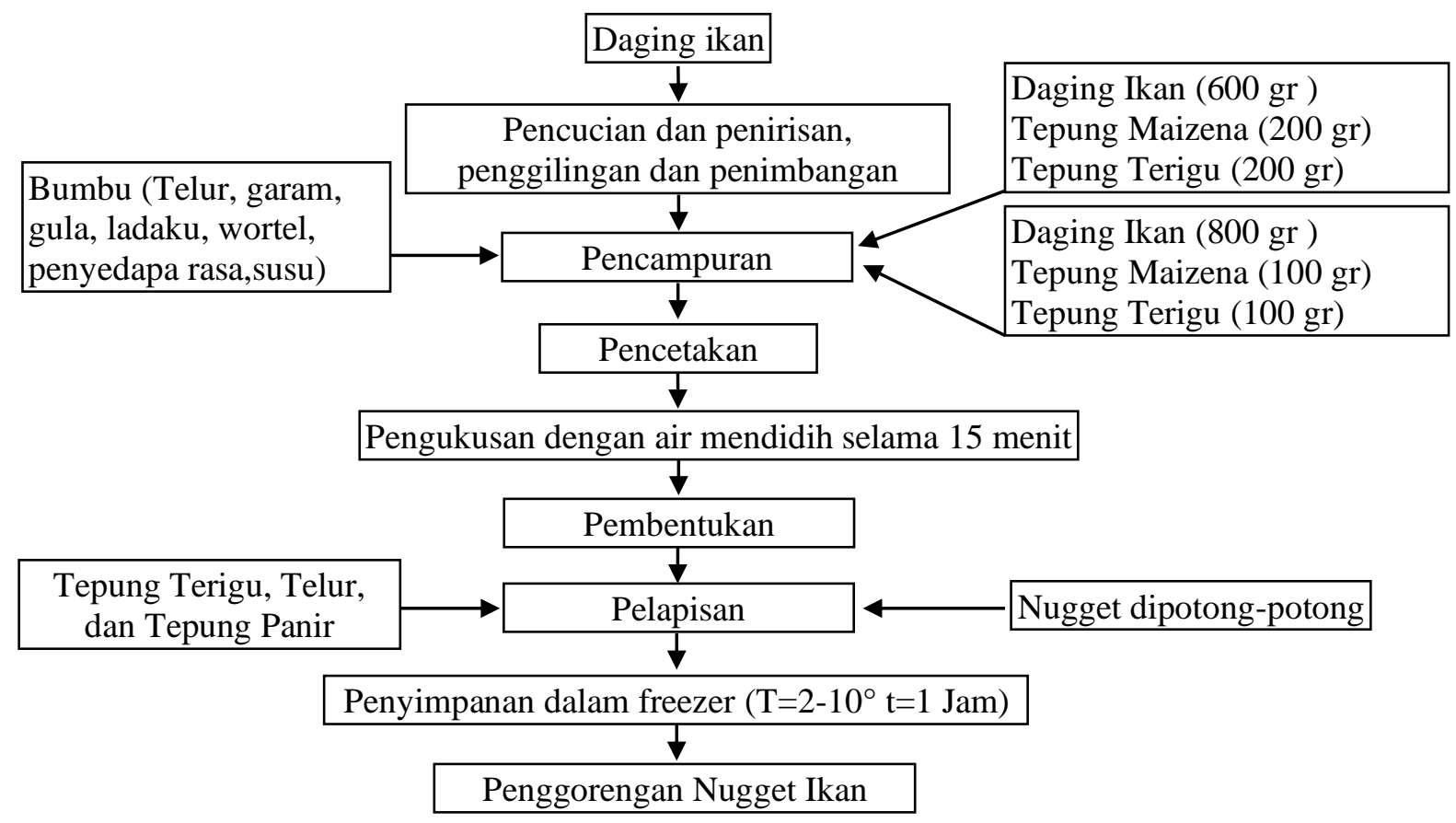

Gambar 4. Prosedur pembuatan nugget ikan

Perbedaan prosedur pembuatan kaki naga dan nugget ikan adalah pada pembuatan kaki naga tidak menggunakan tepung maisena dan susu, selain itu kaki naga dibuat berbentuk lonjong ditusuk dengan tongkat es krim untuk pegangan. Gambar 5 memperlihatkan bentuk nugget dan kaki naga ikan.

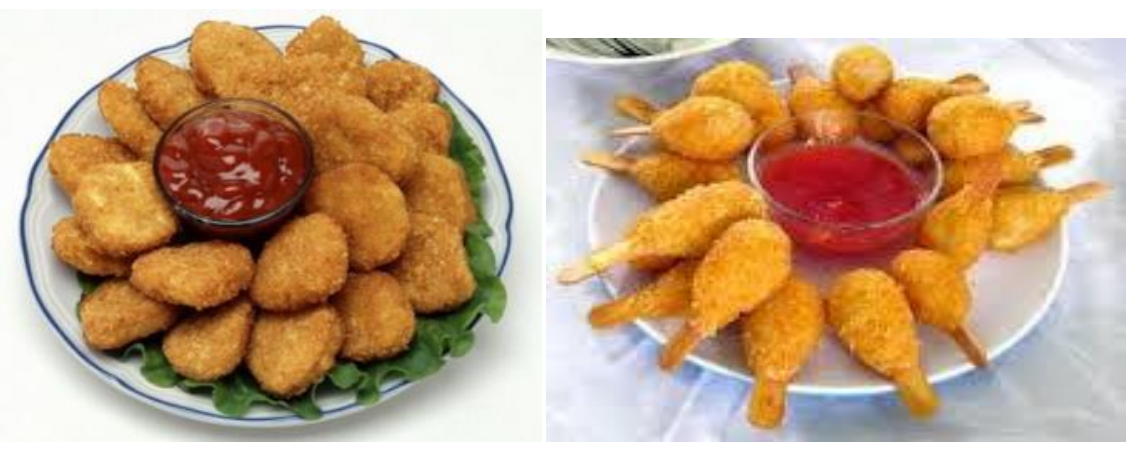

Gambar 5. Nugget dan Kaki naga Ikan

4. Evaluasi (Gambar 6), evaluasi nugget dan kaki naga ikan hasil kegiatan PKM dilaksanakan dengan cara membagikan kuesioner penilaian kepada konsumen meliputi warna, tekstur, rasa dan tingkat kesukaan terhadap nugget dan kaki naga ikan hasil penyuluhan, pelatihan dan pendampingan Tim PKM kepada Wanita Kaum Ibu GPIJS kota Bitung.

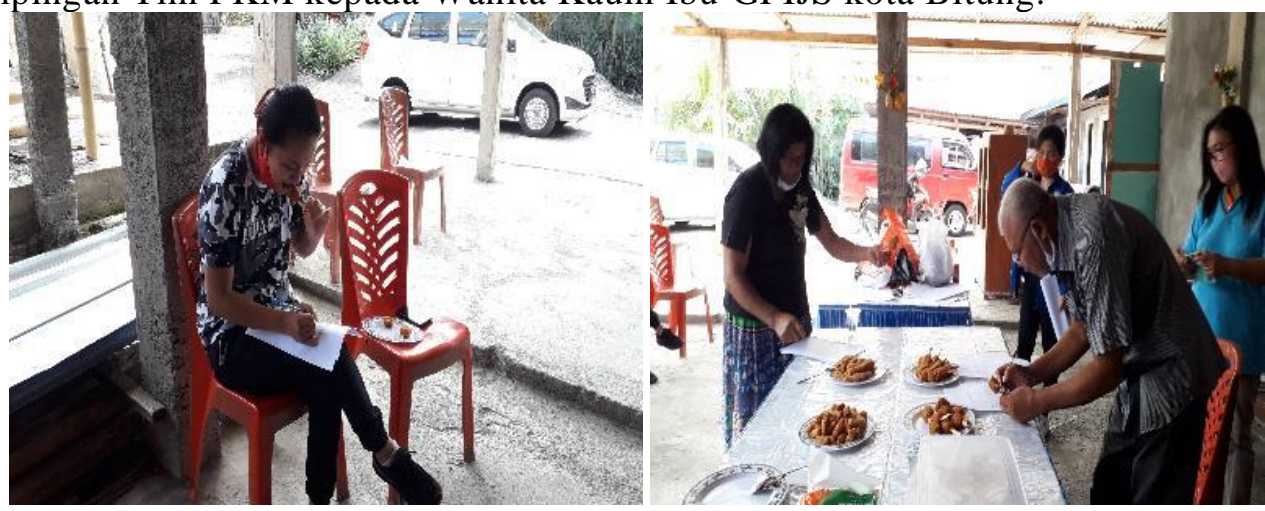




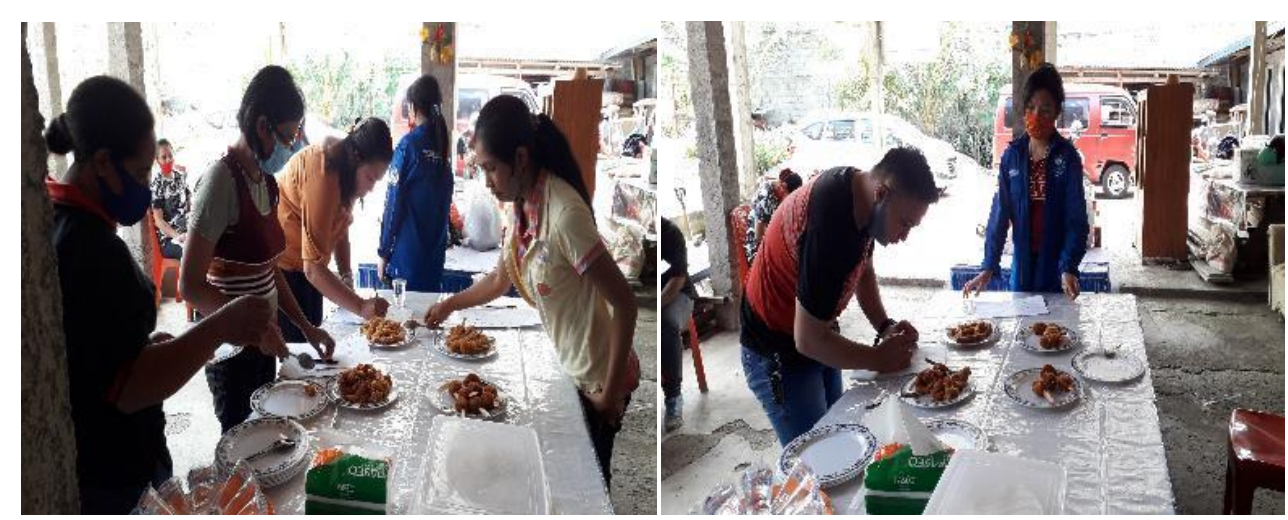

Gambar 6. Dokumentasi Evaluasi secara organoleptik pada produk PKM

\section{HASIL YANG DICAPAI}

Hasil yang dicapai melalui penyuluhan, pelatihan dan pendampingan yang sudah dilakukan oleh tim PKM kepada Wanita Kaum Ibu GPIJS kota Bitung membuat mereka mengerti dan dapat membuat sendiri nugget dan kaki naga ikan yang memenuhi syarat sanitasi dan higienis serta bernilai gizi tinggi sesuai dengan apa yang diajarkan oleh tim PKM. Evaluasi hasil kegiatan PKM juga dilakukan melalui penilaian organoleptik terhadap nugget dan kaki naga ikan hasil kegiatan PKM. Nilai organoleptik ini meliputi warna, tekstur, citarasa dan tingkat kesukaan. Penilaian diberikan oleh 15 orang konsumen dengan cara memberi tanda cek $(\sqrt{ })$ di depan pernyataan yang menjadi pilihan mereka.

\section{Warna}

Yulianti dan Andi Khairun Mutia (2018). Dijelaskan pula bahwa warna adalah parameter pertama untuk menentukan penerimaan suatu produk makanan. Keseragaman warna pada suatu produk ditentukan oleh baik tidaknya pencampuran dalam pengolahan suatu produk (Winarno, 2004).

Warna nugget dan kaki naga ikan layang hasil PKM disajikan pada Tabel 1.

Tabel 1. Nilai Warna Nugget dan Kaki naga Ikan Layang (Decapterus sp).

\begin{tabular}{lcccc}
\hline \multicolumn{1}{c}{ Jenis Produk } & \multicolumn{4}{c}{ Jumlah panelis (\%) yang memberi nilai warna } \\
& Cokelat tua & Cokelat & Cokelat muda & Coklat keemasan \\
\hline Nugget daging ikan 60\% & 0 & 13,3 & 46,7 & 40 \\
Nugget daging ikan 80\% & 0 & 0 & 13,3 & 86,7 \\
Kaki naga daging ikan 60\% & 0 & 6,7 & 60 & 33,3 \\
Kaki naga daging ikan 80\% & 6,7 & 13,3 & 13,3 & 66,7 \\
\hline
\end{tabular}

Data pada Tabel 1, memperlihatkan bahwa lebih banyak konsumen memberi nilai warna terbaik yaitu cokelat keemasan pada nugget dan kaki naga ikan dengan porsi ikan $80 \%$ (perbandingan ikan dan tepung 4:1). Pada nugget ikan dengan porsi ikan 80\% jumlah konsumen yang memberi warna cokelat keemasan adalah sebesar $86,7 \%$ dan pada kaki naga ikan dengan porsi ikan $80 \%$ jumlah konsumen yang memberi warna cokelat keemasan adalah sebesar $66,7 \%$. Hal ini sejalan dengan hasil penelitian Agusta $d k k$ (2020) yang melaporkan bahwa panelis lebih menyukai warna nugget dengan porsi ikan yang lebih tinggi yaitu $70 \%$, yaitu warna putih kekuningan, dimana warna putih pada nugget berasal dari daging ikan gabus, sedangkan warna kekuningan pada nugget berasal dari kuning telur, dan bahan pendukung lainnya. Pramita Sirtin $d k k$ (2017) juga melaporkan bahwa kaki naga ikan patin mempunyai warna cokelat keemasan dimana hal ini sama dengan warna kaki naga ikan layang hasil PKM ini, sedangkan nilai warna cokelat keemasan pada nugget ikan layang hasil PKM pada WKI GPIJS kota Bitung ini lebih baik dari warna nugget ikan layang hasil penelitian Utiarahman, $d k k$ (2013) yang disubstitusi dengan tepung ubi jalar putih yaitu konsumen lebih memilih warna nugget kuning kecoklatan dibandingkan dengan kuning keemasan. Dengan penampilan warna kuning keemasan pada nugget dan kaki naga ikan layang hasil PKM ini akan menyebabkan produk ini akan diterima baik oleh konsumen untuk parameter 
organoleptik lainnya. Yulianti dan Andi Khairun Mutia (2018) menyatakan bahwa warna adalah parameter pertama untuk menentukan penerimaan suatu produk makanan, dimana keseragaman warna pada suatu produk ditentukan oleh baik-tidaknya pencampuran dalam pengolahan suatu produk.

\section{Tekstur}

Nilai tekstur nugget dan kaki naga ikan layang dapat dilihat pada Tabel 2.

Tabel 2. Nilai Tekstur Nugget dan Kaki naga Ikan Layang (Decapterus sp.).

\begin{tabular}{lcccc}
\hline \multirow{2}{*}{ Jenis Produk } & \multicolumn{4}{c}{ Jumlah panelis (\%) yang memberi nilai tekstur } \\
& Tidak padat & Agak padat & Padat & Sangat padat \\
\hline Nugget daging ikan 60\% & 0 & 26,7 & 66,6 & 6,7 \\
Nugget daging ikan 80\% & 6,6 & 26,7 & 26,7 & 40 \\
Kaki naga daging ikan 60\% & 6,7 & 13,3 & 73,3 & 6,7 \\
Kaki naga daging ikan 80\% & 6,7 & 26,7 & 66,6 & 6,7 \\
\hline
\end{tabular}

Data pada Tabel 2, memperlihatkan bahwa lebih banyak konsumen memberikan nilai tekstur padat pada nugget dan kaki naga ikan layang. Menurut panelis tekstur padat menyebabkan nugget dan kaki naga ikan layang enak waktu digigit. Agusta $d k k$ (2020), menyatakan bahwa nugget ikan gabus dengan porsi ikan yang lebih banyak memberikan tekstur kenyal dibandingkan dengan porsi ikan yang lebih sedikit yang memberikan tekstur lunak. Tingginya protein pada daging ikan mempengaruhi tekstur pada nugget ikan, hal ini disebabkan karena protein miosin dan aktomiosin yang memiliki peranan penting dalam penggumpalan dan pembentukan gel, sehingga jika ikan diproses akan menghasilkan struktur yang kenyal (Widjanarko et al. 2011 dan Rahardiyan .2004 dalam Agusta. 2020).

Tabel 2, juga memperlihatkan bahwa Nugget ikan layang dengan porsi ikan $80 \%$ mempunyai tekstur lebih padat dibandingkan dengan nugget ikan layang 60\%. Hal ini sejalan dengan hasil penelitian Nofrian $d k k$ (2017), yaitu nilai tekstur nugget yang dibuat dengan bahan baku surimi yang lebih sedikit mempunyai tekstur yang kepadatannya lebih kecil, selanjutnya dijelaskan bahwa hal ini disebabkan adanya perbedaan jumlah gel pada formulasi nugget akibat semakin sedikitnya jumlah surimi.

\section{Citarasa}

Nilai citarasa nugget dan kaki naga ikan layang dapat dilihat pada Tabel 3.

Menurut Yulianti dan Andi Khairun Mutia (2018), rasa makanan adalah campuran dari tanggapan cicip, bau dan trigeminal yang diramu oleh kesan-kesan lain yaitu penglihatan, sentuhan dan pendengaran, dimana sebenarnya kenikmatan rasa makanan diwujudkan bersama-sama oleh kelima indra.

Tabel 3. Nilai Citarasa Nugget dan Kaki naga Ikan Layang (Decapterus sp.).

\begin{tabular}{lcccc}
\hline Jenis Produk & \multicolumn{4}{c}{ Jumlah panelis (\%) yang memberi nilai citarasa } \\
& Tidak gurih & Agak durih & Gurih & Sangat gurih \\
\hline Nugget daging ikan 60\% & 0 & 20 & 66,7 & 13,3 \\
Nugget daging ikan 80\% & 0 & 20 & 20 & 60 \\
Kaki naga daging ikan 60\% & 0 & 26,7 & 45,6 & 26,7 \\
Kaki naga daging ikan 80\% & 0 & 13,3 & 20 & 66,7 \\
\hline
\end{tabular}

Data pada Tabel 3, memperlihatkan bahwa lebih banyak konsumen memberikan nilai citarasa sangat gurih pada nugget dan kaki naga ikan layang dengan porsi ikan $80 \%$. Pada nugget ikan dengan porsi ikan $80 \%$, jumlah konsumen yang memberikan nilai sangat gurih adalah sebesar $60 \%$ dan pada kaki naga ikan dengan porsi ikan $80 \%$, jumlah konsumen yang memberikan nilai sangat gurih sebesar 66,7\%. Hal ini sejalan dengan hasil penelitian Agusta $d k k$ (2020) yang melaporkan bahwa konsumen mempunyai nilai rasa tertinggi pada nugget ikan gabus dengan porsi ikan tertinggi yaitu 70\% dibandingkan dengan porsi ikan 60, 50 dan 40\%. Penelitian lainnya yang melaporkan bahwa porsi ikan yang lebih banyak memberikan nilai rasa yang tinggi pada nugget ikan adalah Nofrian $d k k$ (2017), bahwa nugget ikan nila dengan porsi 500g surimi ikan nila mempunyai nilai rasa yang lebih tinggi dibandingkan dengan nugget yang mempunyai 475 dan 
450g surimi ikan nila. Tingginya nilai rasa nugget dan kaki naga ikan layang pada porsi ikan yang lebih banyak disebabkan karena daging ikan mempunyai rasa umami (gurih). Sebaliknya menurut Utiarahman $d k k$ (2013) tepung tapioka mempunyai rasa cenderung tawar. Menurut Widia danAnis (2016), rasa merupakan salah satu indikator yangpenting pada penilaian produk makanan, dimana nafsu makan ditimbulkan oleh bentuk dan warna yang menarik dari indra penglihatan terhadap produk pangan tersebut.

\section{Tingkat Kesukaan}

Nilai tingkat kesukaan nugget dan kaki naga ikan layang dapat dilihat pada Tabel 4. Nilai tingkat kesukaan dimulai dari tidak suka dan meningkat ke agak suka selanjutnya suka dan nilai tertinggi adalah sangat suka.

Tabel 4. Nilai Tingkat Kesukaan Nugget dan Kaki naga Ikan Layang (Decapterus sp.).

\begin{tabular}{lcccc}
\hline \multicolumn{1}{c}{ Jenis Produk } & \multicolumn{3}{c}{ Jumlah panelis (\%) yang memberi nilai Tingkat Kesukaan } \\
& Tidak suka & Agak suka & Suka & Sangat suka \\
\hline Nugget daging ikan 60\% & 0 & 0 & 40 & 60 \\
Nugget daging ikan 80\% & 0 & 0 & 6,7 & 93,3 \\
Kaki naga daging ikan 60\% & 0 & 6,7 & 53,3 & 40 \\
Kaki naga daging ikan 80\% & 0 & 0 & 60 & 40 \\
\hline
\end{tabular}

Data pada Tabel 4 memperlihatkan bahwa sangat menyukai nugget ikan dengan porsi ikan 80\% yaitu sebesar 93,3\%. Hal ini sejalan dengan hasil penelitian Agusta dkk (2020) yang melaporkan bahwa panelis memberikan nilai kesukaan tertinggi pada nugget ikan gabus dengan porsi ikan $70 \%$ dibandingkan dengan porsi ikan yang lebih rendah.

\section{KESIMPULAN}

Melalui kegiatan PKM yang telah dilakukan pada Wanita Kaum Ibu (WKI) Gereja Pekabaran Injil Jalan Suci (GPIJS) Kota Bitung dapat ditarik beberapa kesimpulan:

1. Melalui kegiatan penyuluhan mitra telah memahami tentang kandungan gizi pada ikan khususnya ikan layang, terutama protein dan asam lemak omega-3, pentingnya menjaga kesegaran ikan sebelum diolah, dan diversifikasi olahan ikan merupakan salah satu cara untuk memperpanjang daya awet ikan dan meningkatkan gizi konsumen.

2. Melalui kegiatan pelatihan dan pendampingan mitra dapat menerapkan teknologi pengolahan hasil perikanan khususnya diversifikasi olahan ikan yaitu pengolahan nugget dan kaki naga ikan dengan porsi ikan yang lebih banyak untuk peningkatan gizi keluarga.

3. Melalui evaluasi berupa penilaian organoleptik (warna, tekstur, citarasa dan tingkat kesukaan) produk nugget dan kaki naga ikan layang hasil PKM oleh mitra, diperoleh nilai tertinggi pada produk dengan porsi ikan yang lebih banyak yaitu $80 \%$ ikan.

\section{DAFTAR PUSTAKA}

Agusta F. K, Ayu D. F dan Rahmayuni. 2020. Nilai Gizi Dan Karakteristik Organoleptik Nugget Ikan Gabus Dengan Penambahan Kacang Merah. Jurnal Teknologi Pangan. 14(1): 68-82.

Anonimous. 2007. Peningkatan Peran Sektor Perikanan dan Kelautan Sebagai Sumber Ekonomi. Departemen Kelautan Perikanan RI.

(BSN) Badan Standarisasi Nasional. 2006. Petunjuk Pengujian Organoleptik dan atau sensori. SNI 01-2346-2006. Jakarta; Badan Standarisasi Nasional/

Diana F. M. 2012. Omega Tiga. Jurnal Kesehatan Masyarakat 6(2):113-117.

Dotulong V dan Montolalu L.A.D.Y, 2019. PKM Tentang Pengolahan Nugget Dan Kaki naga Ikan Pada Kelompok Wanita Kaum Ibu (WKI) GMIM Solafide Kelurahan Girian Indah Kecamatan Girian Kota Bitung Provinsi Sulawesi Utara. Jurnal Media Teknologi Hasil PerikananVol. 7, No. 3. Hal: 88-92.

Endang, S.H. 2013. Pengolahan Ikan Secara Tradisional Prospek dan Peluang Pengembangan. Pusat riset Pengolahan Produk dan Sosial Ekonomi Kelautan dan Perikanan. Jakarta.

Maarse H. 1991. Volatile Compounds in Foods and Beverages. Marcel Dekker Inc 270 Medison Avenue, New York. Printed In The United States of America.

Masita, H. I dan Sukesi. 2015. Pengaruh Penambahan Rumput Laut terhadap Kekerasan Nugget Ikan. Jurnal Sains dan Seni ITS Vol. 4, No.1, (2015) 2337-3520 (2301-928X Print). 
Nofrian R, Buchari D dan Desmelati. 2017. Studi Penerimaan Konsumen Terhadap Nugget Surimi Ikan Nila (Oreochromis niloticus). Artikel. Fakultas Perikanan dan Kelautan, Universitas Riau. $12 \mathrm{Hal}$

[Permentan]. Program Diversifikasi dan Ketahanan Pangan Masyarakat Badan Ketahanan Pangan Tahun Anggaran 2013. Kementerian Pertanian. Jakarta.

Poernomo, H.S., 2002. Teknologi Pengolahan Ikan. Departemen Kelautan dan Perikanan. Pusat Pendidikan dan Pelatihan Perikanan.

Pramita Sirtin, Wirnelis Syarif dan Rahmi Holinesti. 2017. Pengaruh Teknik PengolahanTerhadap kualitas Kaki naga Ikan Patin. Artikel Skripsi. Fakultas Pariwisata Dan Perhotelan, Universitas Negeri Padang. 12 hal.

Saparinto C, 2011. Fishpreneurship. Variasi olahan produk perikanan skala industri dan rumah tangga.

Suwetja. 1997. Biokimia Hasil Perikanan Jilid 1. Komposisi Kimia Ikan, Protein dan Lipida. Universitas Sam Ratulangi Fakultas Perikanan dan Ilmu Kelautan.

Utiarahman. G, Harmain R. M dan Yusuf N. 2013. Karakteristik Kimia dan Organoleptik Nugget Ikan Layang (Decapterus sp.) yang Disubtitusi dengan Tepung Ubi Jalar Putih (Ipomea batatas L). Nikè: Jurnal Ilmiah Perikanan dan Kelautan. Volume 1, Nomor 3. Hal: 126-138.

Widya S.R A. H. J, dan Annis C. A. 2016. PeningkatanDayaTerima dan Kadar Protein Nugget Bubstitusi Ikan Lele (Clarias batrachus) Dan Kacang Merah (Vigna angularis). Media Gizi Indonesia, Vol. 11, No. 1. Hal: $106-112$.

Winarno FG. 2004. Kimia Pangan dan Gizi. PT Gramedia Pustaka Utama. Jakarta.

Yulianti dan Andi Khairun Mutia. 2018. Analisa Kadar Protein dan Tingkat Kesukaan Nugget Ikan Gabus dengan Penambahan Tepung Wortel. Gorontalo Agricuture Technoloy Journal. Volume 1. No.1. P-ISSN 2614-1140, EISSN:2614-2848. Hal: 37-41. 